\title{
CORPOS ENCARCERADOS EM CENA
}

\author{
Marilene Rosa Nogueira da Silva *
}

RESUMO: $O$ ensaio expõe os riscos da travessia entre a linguagem visual e textual em suas diferentes matrizes discursivas.Ilumina quer seja no manifesto de uma ação coletiva do Grupo de Informação sobre a prisão -GIP, no diário/depoimento de um sobrevivente do Carandiru ou nos filtros ativados pelo chamado cinema verdade, o caráter ficcional, não do filme com sua impressão de realidade porém, dos jogos de visibilidades e enunciabilidades que engendram a política do olhar que informa, conforma e, ainda justifica a prisão na atualidade.

Palavras chaves: História; discurso; imagem; corpo; prisão.

\begin{abstract}
The article exposes the crossing way risks between the visual and textual languages in different perspectives of discussion. It lights up even in a collective action by an informative prison group -GIP in a Carandiru's survivor testimony influenced by The real cinema, its fictional character, not related to the movie and its impression of reality but also the game of visibilities and manifests that compose the policy of the look informing, conforming and justifying the prison today .
\end{abstract}

Keywords: History; speech; body; image; prison

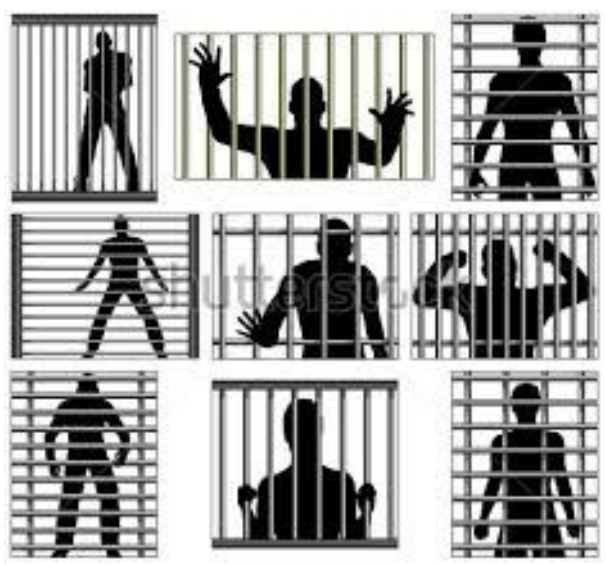

( Tawng, 2009')

Costuma-se dizer que ninguém conhece verdadeiramente uma nação até que tenha estado dentro de suas prisões. Uma nação não deve ser julgada pelo modo como trata seus cidadãos mais elevados, mas sim pelo modo como trata seus cidadãos mais baixos.

Nelson Mandela

\footnotetext{
* Professora Associada da Universidade do Estado do Rio de Janeiro; membro efetivo do Programa de Pós Graduação em História-PPGH/UERJ; Coordenadora do Laboratório do Estudo das Diferenças e Desigualdades Sociais-LEDDES/UERJ ; Procientista da FAPERJ desde 2009; e-mail marilene.silva@uerj.br

${ }^{1}$ Ilustração do artista identificado como Tawng: "jogo, editable, vetorial, projetos, homens, atrás de, prisão, barras.. ID csp1597741. Fonte: http://www.canstockphoto.com.br/encarcerado-1597741.html

Dossiê Transversos: O Corpo na História e a História do Corpo, Rio de Janeiro, v. 05; n. 05; Ano 02. dez. 2015.
} 
$\mathrm{Na}$ condição de diretora narradora ativo uma figura dos tempos do cinema mudo - o explicador, um homem de pé, com um longo bastão que apontava os personagens na tela e descrevia o que estavam fazendo. Não tenho a tela, não tenho o filme, não tenho o bastão entretanto, aposto na imagem/discurso para enunciar uma história do possível e seus efeitos de poder que segundo Foucault

\begin{abstract}
(...)mostra aquilo que é nem sempre foi, isto é, que é sempre na confluência de encontros, acasos ao longo de uma história frágil, precária que se formaram as coisas que nos dão a impressão de serem as mais evidentes. Aquilo que a razão experimenta como sendo sua necessidade, ou aquilo que antes as diferentes formas de racionalidade dão como sendo necessária, podem ser historicizadas e mostradas as redes de contingências que as fizeram emergir.((Foucault, 1983 apud Rago, 2004: 52).
\end{abstract}

A forma de ensaio, experiência modificadora de si e não um mero jogo simplificador da comunicação, exercício de pensamento que assume os riscos do engajamento pessoal ancora a reflexão. No caso, permite problematizar como um mundo conectado em tempo real com as múltiplas espacialidades visuais e virtuais convive com os territórios fixos para os considerados desajustados, famintos, dependentes, insubordinados. Como se ressignifica e amplia o discurso controlado, selecionado, reorganizado e redistribuído por um certo número de procedimentos que fazem emergir corpos subjetivados pela carceralização.

Proponho entrelaçar três ordens complexas de problema: o conceito ou experiência do corpo como um saber que se coloca no centro das relações de poder; o encarceramento como razão punitiva que informa o discurso liberal enunciado como arte de fabricar liberdades, quando o custo desta liberdade seria a segurança; a uma política do olhar provocado pelo cinema com seu tempo complexo, estratificado em presentes, passados, futuros que ativam memórias e expectativas. Assim, da tecnologia política do corpo que se liga a uma determinada política da imagem aos jogos de visibilidades e dizibilidades do chamado cinema do real faz aparecer nas falas anônimas significadas, as práticas de subjetivação e invenção de modos de relacionamento do e no espaço prisional. Aposto na complementaridade entre imagem e palavra. Afinal a iconicidade necessita da verbalidade para significar, ou melhor, para expressar a significância. Aproximo-me de um gênero cinematográfico, o documentário nomeado de maneira variada como cinema direto, cinema do vivido, cinema verdade, cinema da realidade, cinema de não ficção, o que por si só indica a complexidade da proposta. Neste ensaio, passo a defini-lo como manifesto por seu caráter de denúncia ao iluminar prisioneiros/as em suas táticas diferenciadas do viver em

Dossiê Transversos: O Corpo na História e a História do Corpo, Rio de Janeiro, v. 05; n. 05; Ano 02. dez. 2015. 
confinamento, uma arte peculiar de morar em cubículos² ( Scudder, 2012).

Não pretendo decompor os domínios da produção técnica, muito menos da complexidade dos conceitos relativos ao discurso cinematográfico. Ou seja, fazer uma descrição plástica dos planos no que diz respeito ao enquadramento, composição, ângulo ao som -por exemplo, off e in e à estrutura do filme (planos, cenas, sequências). Elementos de uma linguagem secreta, que no dizer de Jean Carrière $(1931)^{3}$ estaria para além da imagem propriamente dita, embora esta seja a sua forma maior. O roteiro, a música, o som e o silêncio, a luz e a sombra, as cores, o corte, a montagem, a oralidade, a teatralidade, os movimentos voluntários e involuntários produzem uma escritura uma narrativa que ativa a sensação de se penetrar numa outra dimensão, criando um choque de realidade, um tempo mítico no qual a arte trapacearia a vida no dizer de Lucena ( 2002 ,p.41). Em outras palavras, na lógica do documentário a vida trapacearia a arte ao estetizar a existência dos habitantes do país dos calças beges ${ }^{4}$.

Essa inquietação mobilizou em outro tempo e lugar a criação do GIP-Grupo de Informação sobre as Prisões, composto por magistrados, advogados, jornalistas, médicos, psicólogos e, especialmente, por detentos. O manifesto escrito e lido por Foucault na capela Saint-Bernard de Montparnasse foi distribuído à imprensa em 8 de fevereiro de 1971. A ideia era criar condições de comunicação entre prisioneiros, falar de prisão à prisão, de cela a cela e, também com a população, tornando conhecidas as práticas prisionais como um saber comum e condenado $^{5}$. O plano não era sugerir reformas pois, no dizer de Foucault: "nós não sonhamos com uma prisão ideal: desejamos que os prisioneiros possam dizer o que é intolerável no sistema de repressão penal”. (Apud ERIBON, 1989, p. 241). A pergunta mobilizadora era: - Pode descrever as condições da vida na prisão? Respostas dos presos: Não. Você não pode descrever (...) você tem que vivê-la.

\footnotetext{
${ }^{2}$ Título da tese de doutorado- A Arte de morar em cubículos: Um diagrama auto/biográfico com Nietzsche e prisioneiros sobre a prisão que tive o prazer de examinar em 2012 no Programa de Pós-Graduação em Educação da Universidade Federal de Mato Grosso.

${ }^{3}$ É roteirista de diversos filmes do Cinema Europeu entre os quais Tambor (1979); Brincando nos Campos do Senhor(1991);A Bela da Tarde( 1966); O Fantasma da Liberdade (1973) e Este Obscuro Objeto do Desejo( 1977) estes três últimos em colaboração com Luis Buñuel e também de alguns roteiros que investem na relação com a História, como Danton- O processo da Revolução( 1982)

${ }^{4}$ Referência ao uniforme dos apenados do Carandiru no rap de Jocenir e Mano Brown: "minha palavra de honra me protege pra viver no país das calças bege"

${ }^{5}$ Ver Toscano, Alberto. O Intolerável, investigação dos Documentos do GIP. Os cinco livros acompanham as reivindicações dos presos, combinando questionários e inquéritos, textos e declarações de rebeliões prisionais, relatórios de psiquiatras da prisão, um dossiê sobre a morte de George Jackson e o movimento da prisão de negros nos EUA, da correspondência e informações sobre a onda de suicídios nas prisões francesas A descrição densa faz aparecer a situação dos diferentes estabelecimentos, reunindo uma antologia das declarações representativas, tematicamente classificadas in https://viewpointmag.com/2013/09/25/the-intolerable-inquiry-the-documents-of-thegroupe-dinformation-sur-les-prisons/O Intolerável-Investigação: os documentos do Groupe d'information sur les prisões .Acesso em 28/02/2015 às 11:30 horas.
}

Dossiê Transversos: O Corpo na História e a História do Corpo, Rio de Janeiro, v. 05; n. 05; Ano 02. dez. 2015. 
Transcrevo o texto provocador deslocando-o para os outros corpos sem rostos em outro tempo e lugar. A motivação seria a mesma, fazer aparecer o sujeito submetido ao controle, dependência e vulnerabilidade do sistema carcerário que a força da lei, define e fixa como uma identidade - o/a detento/a. Afirma o manifesto

Nenhum de nós pode ter certeza de escapar à prisão. Hoje, menos do que nunca. Sobre nossa vida do dia-a-dia, o enquadramento policial estreita o cerco: nas ruas e nas estradas, em torno dos estrangeiros e dos jovens. O delito de opinião reapareceu: as medidas antidrogas multiplicam a arbitrariedade. Estamos sob o signo de "vigiar de perto". Dizem-nos que a justica está sobrecarregada. Nós bem o vemos. Mas, e se fora a polícia que sobrecarregou? Dizem-nos que as prisões estão superpovoadas. Mas se foi a populacão que foi super aprisionada?

Publicam-se poucas informações sobre as prisões; é uma das regiões escondidas dos nosso sistema social, uma das caixas pretas de nossa vida.(...) Propomo-nos a fazer saber quem entra, como e por que se vai parar nela, o que se passa ali, o que é a vida dos prisioneiros, do pessoal da vigilância, como são os prédios, a alimentacão, a higiene, como funciona o regime interno, o controle médico, as oficinas, como se sai dela e o que é, em nossa sociedade, ser um daqueles que saiu.

Essas informações, não é nos relatórios oficiais que as encontraremos. Nos as perguntaremos àqueles que, por uma razão qualquer, tem uma experiência da prisão ou uma relação com ela. Nós lhes solicitamos que entrem em contato conosco e que nos comuniquem o que sabem. Redigiu-se um questionário que nos pode ser pedido. Logo que forem bastante numeroso serão publicados

Não cabe a nós sugerir uma reforma. Queremos apenas fazer conhecer a realidade. E fazer conhecê-la , imediatamente, quase a cada dia, pois o tempo urge. Trata-se de alertar a opinião e de mantê-la em alerta. Buscaremos usar todos os meios de informação: cotidianos, hebdomadários, mensais. Apelamos, portanto, a todas as tribunas possiveis.

Enfim, é bom saber o que nos ameaça; mas também é bom saber como se defender. Uma de nossas primeiras tarefas será publicar um pequeno Manual du parfait arrête( Manual do perfeito detido), acompanhado evidentemente de um Avis aux arrêteurs ( Aviso aos detentores)

Todos os que quiserem informar, ser informados ou participar do trabalho podem escrever ao GIP: Rua Vaugirard, no $² 85$, Paris-XV ${ }^{6}$ (sublinhados meus)

Lá se vão 34 anos do GIP, do corpo a corpo nas ruas e praças exigindo informação, não de cunho institucional e burocrático mas a que permitisse significar o que era ser um/a prisioneiro/a. Ação que merece ser ativada neste presente intolerável de naturalização da prisão como lugar de punição. Do espaço heterotópico ${ }^{7}$ para desviantes, fruto da utopia civilizatória transformada em política pública que emergiu como arquitetura falante ${ }^{8}$ de uma certa ciência da criminologia de matriz racialista ao depósito contemporâneo dos consumidores falhos resultantes

\footnotetext{
${ }^{6}$ Foucault, Michel in Barros, Manoel ( org) Ditos e Escritos vol.IV- Estratégias de Poder -Saber. Rio de Janeiro: Forense Universitária, 2006. "baseados em seus modelos foram criados o GIS ou Grupo de Informação- Saúde, retirando a compartimentagem entre médicos e doentes; o GIA, ou Grupo de Informação sobre Asilos, o GISTI ou Grupo de Informação e de Suporte aos Trabalhadores Imigrantes" pp 1-3

${ }^{7}$ Esse lugar estranho, essa noção aparece primeiro por Foucault em As Palavras e as coisas ( 1966) é enunciado na conferência proferida na Tunísia em 14 de março de 1967. Após esse dito somente reapareceria vinte anos mais tarde, precisamente, em 1984, publicado no quinto número do periódico francês. "Architecture - Mouvement Continuité, traduzido em 1986 por Jay Miskowiec como "Of Other Spaces", em Diacrites.

${ }^{8}$ Casa de Correção da Corte mais tarde Complexo Frei Caneca, o mais antigo presídio do Brasil inaugurado em1850 no Rio de Janeiro capital do Império.

Dossiê Transversos: O Corpo na História e a História do Corpo, Rio de Janeiro, v. 05; n. 05; Ano 02. dez. 2015.
} 
dos jogos de força do capitalismo, quando dependendo da classe dos indivíduos os levariam ao poder ou a prisão.

Vivemos mais do que nunca sob a égide do encarceramento. Por mais patéticos que sejam os pronunciamentos de "bastas à impunidade" exibidos nas diferentes mídias pelos defensores da maioridade penal, ou ainda pelas autoridades de um modo geral, contrastam com as imagens de presos amontoados como animais em jaulas. Se a imprensa e seus articulistas são econômicos em mostrar as reais causas do problema penitenciário, oferecem-nos fartos dados que, se lidos com cuidado, ajudam a montar um quebra-cabeça complexo. Por exemplo, o levantamento de $2014^{9}$ confirma que o hiperencarceramento no Brasil seria apenas superado pelos EUA, Rússia e China. No relatório de 146 páginas são apresentados os eixos que deveriam orientar a política nacional de melhoria dos serviços penais e redução do deficit carcerário, a humanização das condições, a integração social e modernização, o que acaba por reafirmar não apenas a precarização, mas a naturalização e ampliação da lógica positivista que produz a criminalização. Questões pertinentes formuladas por " especialistas" para "especialistas" destacam a importância do conjunto de dados como uma possibilidade de pesquisa e análise da realidade vivenciada, diariamente, por mais de 600 mil pessoas privadas de liberdade, milhares de familiares dessas pessoas e milhares de trabalhadores dos serviços penais.

Foram utilizados descritores para auxiliar o preenchimento e adequação de opções de respostas de modo a contemplar os cenários dos estabelecimento prisionais como ferramenta de gestão ao perfil da população carcerária. Enfatiza os limites da coleta e as ausências como por exemplo: de São Paulo que não atende a chamada( estado responsável por mais de um terço da população prisional brasileira); das pessoas sob custódia nas delegacias ou estabelecimentos similares administrados pelas secretarias estaduais de segurança pública. $\mathrm{O}$ aspecto indiciário do diagnóstico informa e ao mesmo tempo dilui o impacto ao deslocar para lógica matemática impressa em gráficos e tabelas, os 607.731 corpos jovens, pobres acampados em celas lotadas e, em promiscuidade absoluta. Assim, da ficção dos números à ficcionalização do real ou, melhor dizendo, aos efeitos de realidade produzido pelo chamado cinema do real que ilumina os cárceres e, em especial, os/as encarcerados/a.

\footnotetext{
9 Levantamento Nacional de Informações Penitenciária- InFopen- junho de 2014; DEPEN - Departamento Penitenciário Nacional- Ministério da justiça- Coleta de dados.. A plataforma de preenchimento foi desenvolvida através de uma parceria com o Fórum Brasileiro de Segurança. publica ( FBSP) Renato campo Pinto de Vitto, Diretor geral de Departamento Penitenciário nacional e José Eduardo Cardoso Ministro da justiça. Ver http://www.justica.gov.br/noticias/mj-divulgara-novo-relatorio-do-infopen-nesta-terca-feira/relatorio-depen-versaoweb.pdf acesso em 20 de fevereiro de 2015.
}

Dossiê Transversos: O Corpo na História e a História do Corpo, Rio de Janeiro, v. 05; n. 05; Ano 02. dez. 2015. 


\section{É tudo verdade ${ }^{10}$ ?}

O fotografo procede por intermédio da objetiva a uma verdadeira captação do registro luminoso a uma moldagem (...) mas o Cinema realiza o paradoxo de moldar-se sobre o tempo do objeto e de captar, além do mais, o registro de uma duração(...) (BAZIN, 1991: p. 151)

O filme como materialidade, uma coisa boa para pensar os múltiplos tempos dessa história do possível. Uma história lacunar, descontínua com seus planos e cortes móveis de duração, produtores de narrativas pautadas por imagens em movimento nomeadas misé-en-scene. No caso do documentário o que está em cena é o registro que articula tecnologia à subjetivação e seus efeitos de realidade na direção de um olhar comprometido, no dizer de Renov (2005, p.254). Uma aposta na coragem da verdade que ativa, numa versão contemporânea, a parresia recuperada por Foucault nos seus últimos escritos:

$\mathrm{Na}$ análise da parresia, vamos encontrar, perpetuamente, essa oposição entre o saber inútil que diz o ser das coisas e do mundo, e o dizer a verdade do parresiasta que sempre se aplica, questiona, aponta para indivíduos e situações a fim de dizer o que são na realidade, dizer aos indivíduos a verdade deles mesmos que se esconde a seus próprios olhos, revelar sua situação atual, seu caráter, seus defeitos, o valor da sua conduta e as consequências eventuais da decisão que eles viessem a tomar. $\underline{\mathrm{O}}$ parresiasta não revela a seu interlocutor o que é. Ele desvela ou ajuda a reconhecer o que ele, interlocutor é (FOUCAULT, 2011: p.19) (sublinhados meus)

Nos curtas e longas de uma recente filmografia sobre o tema não seria apenas a "força da lei" como criadora do apenado em suas formas da inscrição e inserção que rege o processo penal porém, de modo especial, a produção discursiva da palavra cujo foco estaria nos encarcerados/as instigados/as a falar de si e, consequentemente, da sua condição. Inventa-se uma microhistória da prisão que, de forma indiciária apresenta diferentes sujeitos em suas diferentes experiências destacadas nos títulos abaixo:

$\underline{\text { Cativas - presas pelo coracão }}$ (2001) e Visita Íntima ${ }^{11}$ (2005) de Joana Nin. Tanto o Curta de 2001 e depois o longa de 2005 problematizam a experiência do amor no cárcere. São relatos de mulheres que conheceram os companheiros na penitenciária e de outras que o visitam há décadas. Mulheres que expõem a vida amorosa atravessada e conformada pelos constrangimentos e privações do cotidiano da prisão.

Se eu não tivesse o amor- (Brasil 2008/2009- 47 min ) Geysa Chaves a história de cinco mulheres condenadas por envolvimento direto ou indireto nos crimes idealizados e

${ }^{10}$ É tudo verdade Festival Internacional de Documentários, cuja primeira edição ocorreu em 1996. Desde 2001, promoveu em parceria com o CINUSP quatro conferências Internacionais de Documentários: 2002- Imagens em Conflito; 2003- Imagens da Subjetividade; 2004- O documentário Hoje. Para celebrar a décima edição do É tudo Verdade foi publicada a ontologia o Cinema do Real organizado por Maria Dora Mourão e Amir Labaki. São Paulo : Cosac Naif, 2005

${ }^{11}$ https://vimeo.com/35189302

Dossiê Transversos: O Corpo na História e a História do Corpo, Rio de Janeiro, v. 05; n. 05; Ano 02. dez. 2015. 
executados por seus namorados, maridos e/ou companheiros. O filme revela o drama e os conflitos vividos por elas dentro e fora do cárcere. No caso, a penitenciária feminina Talavera Bruce. $^{12}$

É pó, é pedra, é o vício no meio do caminho- Dirigido pelos adolescentes Internos no CASE: R.F.C. / B.H.P.O. / S.R.A. / R.C.S. / M.G.P. / D.A.S. / F.S.R. Produtor: Movimento do Vídeo Popular. Brasil, duração: 15'.2008. Vindos de diferentes bairros periféricos de Goiânia e cidades do interior de Goiás, meninos com diferentes trajetórias de vida se encontram no CASE e contam um pouco de sua história e sonhos até chegar ao envolvimento com o crack, que tem levado um número cada vez maior de jovens à privação de liberdade.

$\underline{\text { Pena Perpétua }}{ }^{13}$ diretor: Júlio César Lucena e Luana Nascimento Brasil/duração: 10'04" ano: 2008 problematiza um momento errado, uma escolha infeliz e um arrependimento eterno. Pena perpétua revela a difícil vida de ex-detentos que mesmo em liberdade são prisioneiros da própria sociedade.

$\underline{\text { Sem Pena }}{ }^{14}$ direção Eugenio Puppo/- documentário. Brasil 2014, aborda a questão do sistema carcerário brasileiro, com seus preconceitos, limitações e desafios. O jogo de linguagem do título provoca o espectador para uma experiência. Ao invés dos números, problemas de gestão e denúncias de superlotação nas prisões, o diretor inquire sobre a função da cadeia e a noção de justiça.

$\underline{L e i t e ~ e ~ F e r r o ~}^{15}$ Primeiro longa da diretora Cláudia Priscila, produzido por Kiko Goifman e Jurandir Muller,(Brasil 2009/70 min) focaliza a amamentação, sexo, drogas e religião no cárcere. Expõe as dificuldades do Centro de Atendimento Hospitalar à Mulher Presa (CAHMP), uma instituição em São Paulo que abrigava mulheres em fase de aleitamento após darem a luz. Mães e bebês ficam juntos atrás das grades, mesmo que por pouco tempo, já que depois de quatro meses a criança vai para outra pessoa da família, a uma instituição ou é adotada, às vezes até de maneira ilegal.

Desta mostra selecionei os premiados documentários Justiça ${ }^{16}$ e Prisioneiro da Grade de Ferro - Auto Retratos. ${ }^{17}$ No Justiça Maria Augusta faz aparecer tanto a face inquisitorial e arbitrária da atividade policial nas ruas e nas delegacias, quanto a acusatorial que normaliza

\footnotetext{
${ }^{12}$ https://www.youtube.com/watch?v=TF8S5oGkL-c

${ }^{13} \mathrm{http}: / /$ curtadoc.tv/curta/comportamento/pena-perpetua/

${ }^{14}$ https://www.youtube.com/watch?v=C60587HKj34

${ }^{15}$ https://www.youtube.com/watch?v=y1 mf5DqYDbY

${ }^{16}$ Justiça de Maria Augusta Ramos 2003. http://www.youtube.com/watch?v=r8vaMUOHQNY

${ }^{17}$ Prisioneiro da Grade de Ferro- Auto Retratos de Paulo Sacramento 2003 Casa de Detenção de São PauloCarandiru-http://www.youtube.com/watch?v=dlIv7Pg5Ud0;

Dossiê Transversos: O Corpo na História e a História do Corpo, Rio de Janeiro, v. 05; n. 05; Ano 02. dez. 2015.
} 
magistrados e advogados dos tribunais aos cárceres. As cenas gravadas durante as audiências realizadas no Tribunal de Justiça do Rio de Janeiro (no primeiro semestre de 2003) apresentam o primeiro momento da instrução criminal antes do julgamento. Na ocasião os atos, traduzidos em autos, transformam-se num problema jurídico que, debatido na imparcialidade que deveria reger o ritual. Entretanto, nos tribunais não são julgados apenas os crimes porém, em especial, os diferentes tipos de indivíduos criminosos.

A câmera de Justiça ilumina a trama, seus sujeitos e hierarquias: o juiz, o promotor, o defensor e réu, capturando as normas de condutas. Faz emergir no teatro da seriedade burguesa o jogo das aparências na batalha verbal que define e organiza as regras e a quem se permite jogar. Reatualiza o poder de sedução e sacralização presente no sentido grego da palavra corte de justiça.

Esta corte é ainda, no sentido pleno o círculo sagrado dentro do qual, no escudo de Aquiles, aparecem sentados juízes. Todo lugar onde se ministra a justiça é um verdadeiro., um lugar sagrado, separado e afastado do mundo vulgar. Os juízes que vão ministrar justiça saem da vida comum no momento que vestem a toga e colocam a peruca (HUIZINGA, 1988: p. 88)

O jogo cênico do julgamento registra o momento da subjetivação do condenado e sua identificação pelo artigo criminal que incidiu. Uma câmera estática, como se fosse a máquina que visse toda a cena discursiva, os espaços e espacialidades de um lugar especial- o Fórum de Justiça e reativa a proclamação de Dziga Vertov (1929):

Sou um olho cinético, sou um olho mecânico. Eu uma máquina, mostro a você o
mundo como com sigo vê-lo. Agora e sempre, eu me liberto da imobilidade humana,
estou em constante movimento, me aproximo e me distancio dos objetos. Arrasto-me
sob eles, subo sobre eles. Movo-me a toda brida, lanço-me em alta velocidade dentro
de uma multidão, ultrapasso soldados correndo, caio sobre minhas costas, subo com
um avião, mergulho e voo a grandes altitudes junto com corpos que mergulham e
voam. Agora eu, uma câmera me aventuro ao longo do seu resultante caminho,
manobrando no caos do movimento, registrando o movimento, iniciando com
movimentos compostos das mais complexas combinações. Livre da regra das dezesseis ,
dezessete imagens por segundo, livre dos limites do tempo e do espaço, uno quaisquer
pontos no universo não importa onde os tenha registrado. Meu caminho conduz à
criação de uma percepção nova do mundo. Decifro de uma nova maneira um mundo
desconhecido para vocế

A cena de abertura nos remete ao realismo fantástico do processo kafkaneano e provoca um certo riso grotesco, embaraçado ou mesmo tétrico. Descrevo o diálogo mantendo todas as incorreções gramaticais que marcam e demarcam as diferenças

-Tomada 1 - um corredor escuro, uma sombra que vai se configurando como uma pessoa sendo empurrada numa cadeira de roda. A aproximação permite identificar que se trata de um policial conduzindo um jovem negro.

\footnotetext{
${ }^{18}$ Como destaca Renov, Michael. "O homem da Câmera de filmar tenha sido produto do cinema mudo e deva por direito estar mais limitado ao registro visual do que ao auditivo, Vertov conseguiu imitar a audição neste filme de 1929 através da imagem de posturas de ouvinte." In Investigando o sujeito: uma introdução in Mourão, Maria Dora; Labaki, Ami (Org. O Cinema do real, São Paulo: Cosac Naif, 2005. p. 246

Dossiê Transversos: O Corpo na História e a História do Corpo, Rio de Janeiro, v. 05; n. 05; Ano 02. dez. 2015.
} 
Tomada 2 - a sala de audiência no tribunal - o juiz num plano superior, ao seu lado numa mesa um pouco mais baixa o escrivão e diante deles o jovem negro.

Afirma o juiz:

- você não é obrigado a responder .- eu lhe pergunto se a acusação é verdadeira?

O jovem negro:-Não

-Então não é verdadeira. Como se deu a sua prisão?

- Eu estava na Dias da Cruz no carnaval do Méier. Começou uma confusão por causa de guerra de espuminha e os PM do terceiro batalhão vieram correndo. Os policial começaram a dar tiro pro alto e eu pra me defender entrei na rua e quando estava vindo os três elementos correndo com os negócios na mão. Os PMs mandaram parar mas eles correram e largaram tudo no chão. Eu ia pedir uma carona ao pessoal que transporta jornal quando os policial me abordaram . Cadê os outros que tavam aqui? Não conheço não Tio, mas eles me empurraram, me jogaram da cadeira, me bateram nas costas, no rosto e me levaram pra 25a DP. Chegando lá me fizeram assinar um monte de papel, dizendo se eu não falar vai piorar seu caso. Olha meu chefe, olha doutor, olha como está meu caso, vê se tenho condição de estar roubando casa, como o senhor falou o muro e alto como eu tinha condição de pular muro no estado que estou? (...)

O juiz interrompe o relato e pergunta

- O que você faz na vida?

- Sou guardador de carro

O juiz faz o relato para o escrevente:

- Que não é verdade a acusação, ponto e vírgula que não praticou o fato narrado na denúncia.

Volta a inquirir o jovem:

- Quer dizer que você foi preso no dia de carnaval? Conhecia os três elementos que estavam correndo? (...)

Indaga se o jovem tem advogado e, nesse momento a câmera ilumina a presença de uma mulher -advogada nomeada defensora pública

O rapaz se dirige ao juiz:

- Dr meritíssimo se o senhor for me mandar lá pra DP poderia me dar uma autorização pra me mandar pro hospital. Porque lá no xadrez são 79.

O que você tem? Pergunta o juiz.

-Não pra mim dar uma evacuada eu tenho que ficar me arrastando no chão, pra tomar banho eu não tenho condição é lá eu tenho dificuldade de certas coisas.

-Eu só posso ti remover se houver uma recomendação médica .... Isso é assunto médico, não é assunto de juiz... Se o médico disser você será removido, fora disso não (...)

Você já está assim há muito tempo?

O jovem responde que sim e mais uma vez interrompido pela impaciência do juiz.

-Quando foi preso você não estava na cadeira de roda?

-O quê você já foi preso em cadeira de roda?

O que evidencia a falta de atenção ao relato do jovem.

-Estou assim desde 96. Isso aconteceu comigo porque sou hipertensi e por causa das artéria.

A surpresa na repetição da pergunta.

- Você foi preso em cadeira de rodas?

A defensora vai analisar essa sua situação e vai pedir os direitos que ela acha que você merece (sublinhados meus)

O absurdo reforça o comentário indignado da defensora pública diante das inúmeras e complexas histórias de homens e mulheres, jovens e infames impotentes diante de um Lei grafada em maiúscula como entidade jurídica- "quem está preso? só tem pé de chinelo, ladrão de galinha, o povo mais miserável”. $O$ tratamento desigual na relação processual expõe a ineficácia do sistema judicial brasileiro exibido nos deslocamentos dos tribunais aos cárceres. No caso, do Tribunal de Justiça do Estado do Rio de Janeiro ao interior da Polinter na 25 a delegacia Dossiê Transversos: O Corpo na História e a História do Corpo, Rio de Janeiro, v. 05; n. 05; Ano 02. dez. 2015. 
de polícia carioca onde desemboca o pobre de rua. Sujeito da mutação do estado-providência para um estado penitência ( WACQUANT,2003)que não consegue administrar a onda de delitos e pequenos crimes do cotidiano e do avançar do combate as drogas: são "mulas”, aviões" "olheiros “, "vapores”, "gerentes”, "ladrão-de-galinha”, numa curiosa adjetivação das criaturas de cadeia. As prisões não são mais encarregadas de reconduzir ao trabalho os recalcitrantes, porém contentam-se em estocar os refugos do mercado do trabalho, suas frações extranumerárias. Logo, mais do que a disciplinarização dos indisciplinados a prisão administra as margens. Margens estas iluminadas no documentário. A cena em questão dura apenas quatro minutos, focaliza o juiz e o jovem negro paralítico, enquanto reafirma o espectro grotesco da violência do óbvio no pronunciamento do juiz - A defensora vai pedir os direitos, não que ele tenha, mas que ela acha que ele merece.

O corte e a mudança de plano desloca a câmera para a entrada do Tribunal de Justiça do Estado do Rio de Janeiro. Embora não esteja na cena, destaco as três estátuas de bronze situadas na parte externa do edifício como uma estranha fixação, num estado laico, dos princípios de matriz religiosa apresenta a Justiça como o Cristo Togado que carrega na mão direita o cetro do poder. Nas interpretações divulgadas pelo tribunal ${ }^{19}$, a vara as três esferas representariam os mundos físico, moral e espiritual. $O$ dedo indicador na mão esquerda apontaria a sede do juiz, caracterizando o campo moral da consciência. A Lei simbolizada por Javé, considerado o criador das leis naturais e sobrenaturais, traria na cabeça o triângulo que os antigos usavam para indicar o Pai Eterno; dos seus membros desce a asa única, símbolo da onipresença. No cinto as estrelas de seis pontas lembrariam as constelações; na altura das pernas, as tábuas das leis. Assim a lei estaria entre a Justiça e a Equidade uma figura materna que aparece para pedir misericórdia, uma das características da justiça divina Presença destacada na produção discursiva dos autos nas sessões do tribunal transformado no documentário analisado

\footnotetext{
${ }^{19}$-As esculturas medem cerca de dois metros cada e são de autoria do artista e desembargador Deocleciano Martins de Oliveira, datadas de 1966, confeccionadas a pedido do presidente do Tribunal do antigo Estado da Guanabara, Martinho Garcez Neto para ornamentarem o Fórum central. As estátuas eram um projeto pessoal do magistrado. Ver http://trombudo-centralense/pagina/deocleciano-martins-de-oliveira-ciclo-de-bronze//http://vaporencantado. blogspot.com.br/2010/01/bronze-no-pais-das carnaubas.html.
}

Dossiê Transversos: O Corpo na História e a História do Corpo, Rio de Janeiro, v. 05; n. 05; Ano 02. dez. 2015. 


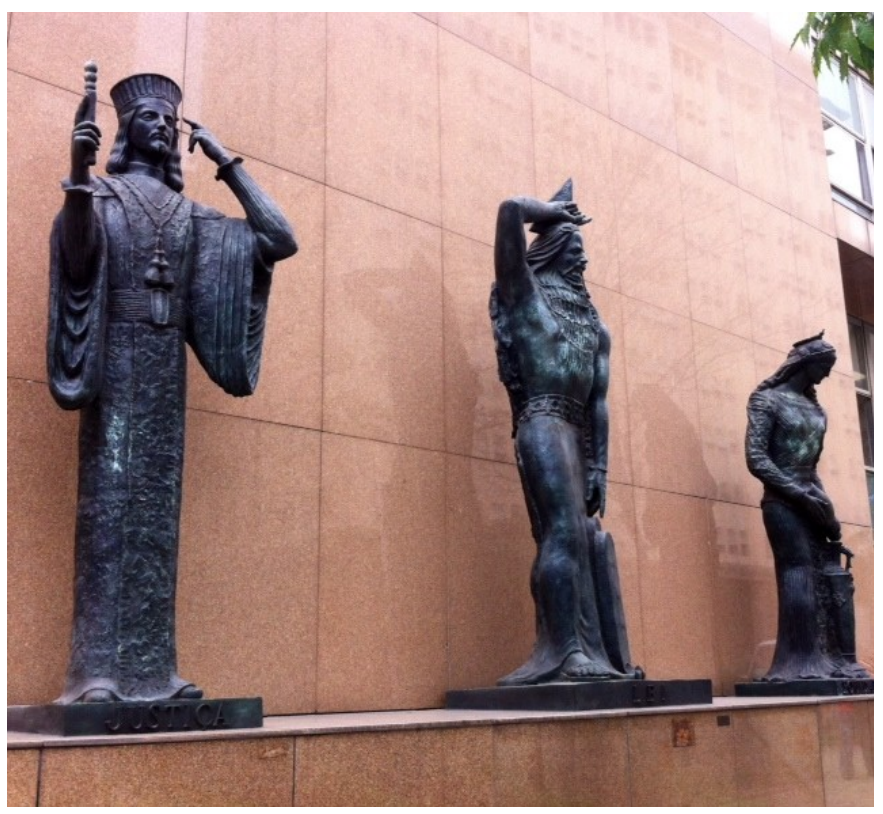

(Foto mrns 2015-Justiça, Lei e Equidade)

O ruído da rua sonoriza a movimentação das pessoas nos corredores das salas de audiências. O caminhar de uma mulher que na sequência seria identificada como a defensora pública coloca em cena os atores sociais e suas historicidades que emergem da inquirição de juízes e juízas que personificam a noção abstrata de justiça . Após o impacto da primeira tomada o jovem negro na cadeira de rodas desaparece, não sabemos seu nome, nem o que lhe aconteceu na 25 DP. Desse momento em diante serão os atos transformados em autos de Carlos Eduardo Lusitano de Castro e Sousa, que conduz a narrativa filmica:

O que faz na vida? a questão que indica que fazer algo na vida- significa trabalhar; balconista numa determinada confeitaria na zona sul do Rio de Janeiro, sabe ler e escrever, cursou até a oitava série. Carlos Eduardo agora subjetivado com o Denunciado pelo promotor de justiça que passa a leitura dos atos: "em 3 de fevereiro de 2003 o denunciado livre e consciente, conduzia o automóvel Corsa placa GL 4031 de propriedade de Vera Lúcia Medeiros que fora produto de roubo em 9 de fevereiro de 2003, na Favela das 5 Bocas.

Ele entra como denunciado, sai indiciado e, sob o olhar da câmera, transferido do Tribunal no camburão (transporte de prisioneiros) à Detenção da $25^{\mathrm{a}} \mathrm{DP}$, localizada no bairro de São Cristóvão na zona norte da cidade. Os efeitos desta captura nos introduz na prisão e nos procedimentos burocráticos da reapresentação após a sessão de instrução. Na direção da cena fecho o foco nas grades, nos indivíduos que desaparecem na multidão de detentos em condições precárias. Descolo a seguir a atenção de Justiça para Prisioneiros da Grade de Ferro que sob a direção de Paulo Sacramento expõe os modos de fazer, ver e falar não apenas do sujeito criminoso, mas da delinquência e, em particular da lógica punitiva. O close up no aprisionado de

Dossiê Transversos: O Corpo na História e a História do Corpo, Rio de Janeiro, v. 05; n. 05; Ano 02. dez. 2015. 
certa maneira, reativa a proposta do GIP. Ao colocar a câmera na mão de detentos para que registrassem os fragmentos da vida normalizada e adaptada à carceragem estimularia um ensaiarse virtualmente. Para além da oralidade essa câmera especial constrói uma narrativa imagética das celas, os instantâneos e enquadramentos transformam o objeto do direito criminal em produtor de múltiplas historicidades: depoentes e entrevistadores todos detentos são alçados à condição de um tipo especial de cine sujeito (LUZ: 1995, p.42).

Será que eles puderam de fato falar? Seria inocente afirmar que sim. O que remete a provocação formulada pela indiana Gayatri Spivak ${ }^{20}$ (2010) sobre o papel mediador do intelectual na produção e controle do discurso que ancora a fala deste outro nomeado subalterno por conta de suas diferenças e desigualdades sociais. O projeto dá visibilidade aos detentos/alunos da oficina de cinema que roteirizam sua condição de condenado num plano de filmagem. Entretanto, não dá pra esquecer que havia uma direção responsável por todo o processo de seleção e corte inerentes a montagem que edita em 123 minutos às 170 horas de gravação, dando sentido ao filme e materialidade a esse artigo.

Descrevo a primeira cena do Prisioneiro: Sob a imagem amarelo/ ocre, com som in off de um apito que vai se intensificando, até que os olhos começam a relacionar a cor amarelada à poeira de uma implosão que dura apenas 1:55 segundos. Da imagem movimento à imagem tempo emerge um entre lugar, o antigo Instituto de Regeneração do Carandiru, penitenciária situada na zona norte da cidade de São Paulo, criada em 1920 "como modelo a ser seguido pelos homens da justiça", exaltada como "maravilha da engenharia penitenciária". O acontecimento que o transforma em escombros ocorreu no dia 8 de dezembro de 2002. O jogo de playback expressa o desejo da pesquisadora de tentar, a partir dos estilhaços e fragmentos, montar o quebra-cabeça das muitas histórias que conformam o objeto prisão. Transcrevo a seguir as palavras que se sobrepõem as imagens da tela, a princípio sem correspondência diegética ${ }^{21}$ afirmam a destruição de uma prisão mas não a ordem punitiva da qual esta emerge:

O sistema carcerário abriga cerca de 250 mil homens distribuídos por aproximadamente 1000 unidades prisionais. Quase metade desse contingente encontrase detida em São Paulo. O maior presídio paulista é também um dos maiores do mundo: a Casa de detenção professor Flaminio Fávero localizada no Complexo

\footnotetext{
${ }^{20}$ Elabora uma leitura crítica das oclusões sobre o terceiro mundo na produção do que nomeia “ Os intelectuais e o poder: conversa entre Michel Foucault e Deleuze , profetas da heterogeneidade do outro porém, segundo Gayatri o que fizeram foi manter e reativar o Sujeito do Ocidente

${ }^{21}$ A diegese é a realidade própria da narrativa ("mundo ficcional", "vida fictícia"), à parte da realidade externa de quem lê (o chamado "mundo real" ou "vida real"). O tempo diegético e o espaço diegético são, assim, o tempo e o espaço que decorrem ou existem dentro da trama, com suas particularidades, limites e coerências determinadas pelo autor. Em Cinema e outras linguagens audiovisuais, diz-se que algo é diegético quando ocorre dentro da ação narrativa ficcional do próprio filme. http://www.dicionarioinformal.com.br/dieg\%C3\%A9tico/
}

Dossiê Transversos: O Corpo na História e a História do Corpo, Rio de Janeiro, v. 05; n. 05; Ano 02. dez. 2015. 
Penitenciário do Carandiru registra em sua história a passagem de mais de 175000 detentos. A Casa de Detenção tornou-se conhecida mundialmente em 1992 quando uma desastrosa ação policial realizada no Pavilhão 9 resultou na morte de 111 presos. O episódio ficou conhecido como o Massacre do Carandiru. O ano de 2002 marcou o fim da Casa de Detenção. Mais de 7000 presos foram removidos para novas unidades prisionais e os Pavilhões 6, 8 e 9 foram implodidos pelo Governador do Estado.

A magia do cinema faz aparecer da poeira as imagens captadas ao longo de sete meses no ano anterior a implosão (2001). Ergue-se na tela, em toda sua monumentalidade, o Carandiru e as formas possíveis do viver na prisão.

\section{Habitar a cela}

(...) a astúcia é possível ao fraco, é muitas vezes apenas ela, como último recursos: Quanto mais fracas as forças submetidas à direção estratégica, tanto mais esta estará sujeita, Traduzindo: tanto mais se torna tática (CERTEAU, 1994: p.101)

Penso a prisão como espaços transversalizados e transversalizantes por e de procedimento de ver e falar, do embate entre o visível e o enunciável, entre as imagens submetidas a determinadas formas de luminosidades e legibilidades ligadas a determinados regimes de verdade e aquelas que a recusam. Como não há um sujeito prévio a subjetividade deve ser produzida como processo, como estética da existência. Constituir novos modos de existência pode se dar de maneira casual, desde que se crie uma necessidade, uma paixão, um ritual e, neste caso, um filme. As entrevistas, as justificativas, mesmo os não ditos, são afirmados e reafirmados por uma direção empenhada em denunciar. Identificados, hierarquizados pela força da lei assassinos, estupradores, ladrões inventam formas de viver no cárcere, numa tentativa de diminuir o tempo que sempre insiste em correr vagarosamente. Demarcam territórios: religiosos, traficantes, marombeiros na malhação do corpo, casais em suas múltiplas sexualidades, sambistas; produtores das peculiares engenhocas que dão conta das necessidades do cotidiano, fabricam armas, bebidas, aparelhos domésticos feitos com todos os tipos de sucatas. O experimento destaca alguns moradores nas suas mutações identitárias de operador e objeto, condenado à aluno da equipe mista composta de professores de cinema de um curso de vídeo ministrado no estabelecimento. Como informa em entrevista o diretor ${ }^{22}$ :

Para eles era muito claro que estavam fazendo um filme mostrando a Realidade e a Verdade, as duas coisas com letra maiúscula, como, aliás, acontece com todos os grupos de rap, que se colocam como porta-vozes de uma verdade.(...) Para eles, e para nós, enquanto estávamos junto com eles, captávamos, sim, momentos da realidade, que depois seriam manipulados, e que estavam sendo manipulados ali de uma maneira muito objetiva, tanto por nós quanto por eles.(...) .O trabalho em conjunto não permitia haver qualquer sentido em separar o que a gente filmou do que eles filmaram,

\footnotetext{
${ }^{22}$ Ver entrevista com Paulo Sacramento e Aloysio Raul ino, respectivamente, diretor e diretor de fotografia que aconteceu no Cine Odeon BR no dia 14 de abril de 2004, após exibição do filme em pré-estreia no quadro da Sessão Cineclube, iniciativa conjunta do Grupo Estação e da Contracampo in http://www.contracampo.com.br/59/entrevistapaulosacramento.htm acesso em 23 de outubro de 2015 às 15:31hrs.

Dossiê Transversos: O Corpo na História e a História do Corpo, Rio de Janeiro, v. 05; n. 05; Ano 02. dez. 2015.
} 
isso não traria nenhum dado novo, muito pelo contrário, empobreceria aquela relação que a gente teve com eles e aquele trabalho que a gente propôs. Teve muito essa autocrítica minha depois de montar aquele filme como um recorte sabendo que aquilo era uma manipulação de uma realidade, uma manipulação que fosse a mais fiel que eu conseguisse fazer do ponto de vista deles, mas para eles aquilo era mesmo a realidade, ou a verdade (sublinhados meus)

$\mathrm{Na}$ medida em que se apresentam aparece na tela a cópia do seu prontuário com foto e número de identificação. Bem ao modus operandi do gabinete antropométrico criado por Félix Pacheco em 1904 na antiga Casa de Correção. Dentre os entrevistados apenas um cumpria pena pelo artigo 121 (matar alguém com reclusão prevista de seis a vinte anos), os demais enquadrados no Art. 157 (subtrair coisa móvel alheia, para si ou para outrem, mediante grave ameaça ou violência a pessoa, ou depois de havê-la, por qualquer meio, reduzido à impossibilidade de resistência: reclusão, de quatro a dez anos, e multas) e no Art. 180 (crime de receptação, adquirir, receber, transportar, conduzir ou ocultar, em proveito próprio ou alheio, coisa que sabe ser produto de crime). ${ }^{23}$ Entretanto, o que a câmera de fato exibe são homens nomeados que relatam sonhos e apresentam habilidades resistindo à prisão na prisão:

Meu nome. Celso Ferreira de Albuquerque , prontuário 153-208 ,entrada 24-04/98art. 157- morando atualmente no Pavilhão 2; Jonas Jonas de Freitas Cruz-prontuário 103-297- art 157- pavilhão 6; José Heleno da Silva - prontuário 153-222 entrada 24/04/98, Art.19- morei 4 anos no pavilhão 8 e estou há um mês no pavilhão 6; Ruben lima da Silva prontuário 082083/08/02/91 - art 157, pavilhão 2 atualmente; João Vicente Lopes prontuário 124047 art. 157- 21-10-99, pavilhão 5; Rubem Jonas do S Santos Batista, 14/01/97, prontuário 149193, art 157- moro no Pavilhão 9; Adailton Cupertino entrada 04/02/92- prontuário 137968-art. 157 sou remanescente do massacre humano que houve no Pavilhão 9 de 92; Joel aparecido da Silva 22/12/99. prontuário 169747- art. 180-pavilhão 7;Max Roberto dos Santos- entrada 15/04/99. prontuário 165386-art 157 pavilhão 7; RonaldoFernando Gomes 13/12/85, prontuário 122-265 art. 157- pavilhão 2 cela 403; Reginaldo Peres entrada 05/08/98prontuário 154332 art. 121 pavilhão 2; Renildo do Nascimento - 05/01/99, prontuário 121553- art 157 pavilhão 5; Kric Mc Claudio Fabiano - 26/04/96 prontuário 100783 art 157 moro no pavilhão 8; Fabiano de Souza Fonseca Filho 31/12/93- prontuário 140752 art 157- Mc da Comunidade carcerária pavilhão 8.

Das celas à triagem, no enquadramento que ilumina a inclusão pela exclusão. A determinação de um sistema fechado que compreende tudo : o cenário, os personagens, acessórios de normalização anunciados na palestra proferida pelo diretor do presídio para uma plateia de homens jovens, negros e mestiços, uniformizados, com o mesmo corte de cabelo, que poderiam ser inseridos nos espaços outros da escola ou mesmo de soldados no serviço militar. Transcrevo o pronunciamento:

- Falamos sobre duas certezas. Primeira certeza, os senhores estão presos não dá pra esquecer. Segunda certeza, os senhores vão sair. Hoje alguns dos senhores estão

$\overline{{ }^{23} \text { http://www.planalto.gov.br/civil_03/decreto-lei/Del2848compilado.htm }}$

Dossiê Transversos: O Corpo na História e a História do Corpo, Rio de Janeiro, v. 05; n. 05; Ano 02. dez. 2015. 
entrando no sistema penitenciário, alguns retornando mas acredito que a maioria está chegando. Estar preso é horrivel !!!Uma vez aqui dentro os senhores estão sendo observados 24 horas por dia. Vejo que a maioria recebeu uma cartilha. Cartilha dos direitos e deveres do preso. Está errado a partir de hoje aqui não existe preso, condenando, sentenciado, ladrão, vagabundo,, maluco, bandidão a denominação correta pra cada um dos senhores e reeducandos. A cadeia está dando muito ênfase ao trabalho. Está correto,_a Constituição manda. Não só o sistema penitenciário de São Paulo, mas o de outros estados, manda por obrigação lhes fornecer trabalho. Alguns senhores conhecem a remissão de pena, três dias trabalhados um dia a menos de pena. Aqui existe trabalho? Existe, Em todos os pavilhões? Sim. Pra todo mundo? Não. Esse é o lado mal. Nenhum dos senhores pediu pra vir preso. Acredito que não estão gostando de estar preso. Lamento. Essa é a prisão. Não sou tão sádico de agora no final lhe desejar boas vindas. Muito obrigado é uma boa tarde. Podem sair. ( 10'54" sublinhados meus)

Conforme define o regulamento a Cartilha é um manual de sobrevivência do novo sujeito-o reeducando no cotidiano da prisão. $\mathrm{O}$ que distinguiria portanto o direito, identificado à lei e aos procedimentos técnicos da normalização seriam , justamento, os dispositivos de controle que se mostrariam no encontro com o poder, no que este diz ou faz dizer, nos seus entrecruzamentos, na provocação de suas forças, no confronto, na resistência, na luta e no desafio, nos jogos políticos que manipulam e nos efeitos produzidos, como bem analisa Foucault em Vigiar e Punir ( 1975) . Logo, os dispositivos lei e norma podem ou não estar implicados, como alerta o pronunciamento do diretor da instituição: os senhores estão sendo observados 24 horas; a Constituição manda, porém...”

Os modos de existência acontecem, para além da espacialidade resultante do emponderamento. O que permite, por exemplo, transformar as celas em moradias, em lugar de trabalho, de reza, diversão e arte. Afinal, é preciso habitar o cárcere, como diz Reginaldo Peres ao apresentar sua academia no pavilhão 2: “ embora já tenha sido encerrada, o esporte é uma força na cadeia".O detento presta seu depoimento sobre as benesses da ginástica para conseguir cumprir a pena e, enquanto, fala coloca as luvas de boxe ativando uma nova identidade - o atleta. Um novo corte muda a cena, ou melhor a cela e o pavilhão onde encontramos Adilson há dois anos na detenção que vai produzindo uma prótese dentária no momento da tomada: "moro no pavilhão 5, exerço a profissão prá ocupar a minha mente e tirar daqui o meu sustento”. Agora a palavra é do Marco que está há dois anos no pavilhão. É o desenhista da ala, faz cópias e ampliações de retratos ao custo de15 reais por cada foto: "é assim que tiro minha cadeia". Outro deslocamento faz aparecer Robson no pavilhão 2 empenhado na construção de um galeão que, de maneira, poética profetiza "graças a Deus ele vai embora primeiro do que eu". Uma satisfação estranha de libertação de sua arte. Dos instantes privilegiados que nutrem o cinema como um sistema que reproduz o movimento reportando-o ao instante qualquer que emerge da decupagem Dossiê Transversos: O Corpo na História e a História do Corpo, Rio de Janeiro, v. 05; n. 05; Ano 02. dez. 2015. 
e, no caso, a cena final desse texto/experimento

\section{Desentocar o pensamento}

A racionalidade não é um dom nem uma condição natural do ser humano. Ao contrário só se pensa quando se é obrigado. Assim, a crítica ao depósito nomeado prisão estimula no dizer de Foucault:

(...) desentocar o pensamento e em ensaiar a mudança; mostrar que as coisas não são tão evidentes quanto se crê, fazer de forma que isso que se aceita como vigente em si não o seja mais em si. Fazer a crítica é tornar difíceis os gestos fáceis demais. Nessas condições, a crítica - e a crítica radical- é absolutamente indispensável para qualquer transformação (1994, p.180)

De manifesto a manifesto ativei os registros da ação pontual do GIP que problematizou os saberes e poderes das prisões para além do jurídico. Da cena discursiva da Paris na década de 70 que fez de um prefácio uma trincheira para uma vida não Fascista ao enquadramento de um corpo numa das celas da Casa de Detenção de São Paulo. Montagem que articula a escrita de Jocenir à Deleuze e Guattari( 2011) para quem escrever nada tem a ver com significar, mas com agrimensar, cartografar, mesmo que seja regiões ainda por vir. Jocenir em seu diário cartografou as situações e reflexões de um corpo encarcerado sobre outros corpos também encarcerados; a rebelião abafada seguida de uma cruel sessão de torturas; as descrições dos esforços para salvar a vida de um companheiro endividado com um traficante, os relatos de um velho viajante do mundo, de 74 anos, cumprindo pena numa prisão de segurança máxima, o contato com médico Drauzio Varella. Para ele escrever seria acima de tudo a tentativa de compartilhar uma experiência- "quero desapertar minha alma, desabafar." O desaperto transformado numa tática de resistência, uma forma de ocupação para vencer o ócio sem dignidade da prisão.

Transcrevo fragmentos do Diário ${ }^{24}$ de quem se propôs a "traduzir o cárcere com um lápis". Um manifesto ritmado na poesia do rap $^{25}$ língua das ruas da Jamaica aos guetos dos negros norte-americanos, chega às favelas e prisões brasileiras traduzidas nos depoimentos dos que sobreviveram ao Massacre do Carandiru² em 1992 mas em especial , a morte social da

\footnotetext{
${ }^{24}$ Jocenir, apresentação: Crítica de Marcelo Rubens Paiva (Folha de São Paulo/Ilustrada - 12 de maio de 2001);- Na

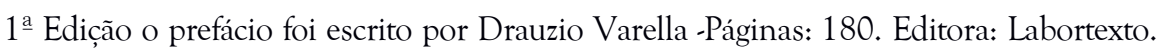

${ }^{25}$ Do inglês-Rhythm and Poetry. As primeiras gravações de Rap datam do início dos anos 1970, com alguns grupos como os Last Poets Gil Scott Heron. Nessa época, tratava-se simplesmente da declamação de um texto sob o ritmo das batidas de tambores africanos sendo a negritude o tema de predileção.

${ }^{26}$ Uma briga de presos no Pavilhão 9 em 1/10/1992 seria mais um tumulto da Casa de Detenção, no complexo do Carandiru, zona norte de São Paulo, porém uma violência intervenção policial resultou em 111 mortes. O episódio ficou conhecido como o Massacre do Carandiru.

Dossiê Transversos: O Corpo na História e a História do Corpo, Rio de Janeiro, v. 05; n. 05; Ano 02. dez. 2015.
} 
prisão

"São Paulo, dia 1ํ de outubro de 1992, 8 horas da manhã.

Aqui estou, mais um dia. Sob o olhar sanguinário do vigia. Você não sabe como é caminhar com a cabeça na mira de uma HK. Metralhadora alemã ou de Israel. Estraçalha ladrão que nem papel. Na muralha, em pé, mais um cidadão José. Servindo o Estado, um PM bom. Passa fome, metido a Charles Bronson. Ele sabe o que eu desejo. Sabe o que eu penso(...) Será que Deus ouviu minha oracão?Será que o juiz aceitou a apelação?(...) Tanto faz, os dias são iguais. Acendo um cigarro, vejo o dia passar. Mato o tempo pra ele não me matar. Homem é homem, mulher é mulher. Estuprador é diferente, né?Toma soco toda hora, ajoelha e beija os pés,e sangra até morrer na rua 10.(...) Lamentos no corredor, na cela, no pátio. Ao redor do campo, em todos os cantos. Mas eu conheço o sistema, meu irmão, há Aqui não tem santo.(...) Desde terça-feira ninguém abre pra nada. Só o cheiro de morte e Pinho Sol. Um preso se enforcou com o lençol. Qual que foi? Quem sabe?, (...) Sete mil homens. Que custam trezentos reais por mês, cada.(...) Dois ladrões considerados passaram a discutir. Mas não imaginavam o que estaria por vir. Traficantes, homicidas, estelionatários. Uma maioria de moleque primário. Era a brecha que o sistema queria. Avise o IML, chegou o grande dia.(...) $\mathrm{O}$ ser humano é descartável no Brasil. Como modess usado ou bombril Claro que o sistema não quis. Esconde o que a novela não diz. Ratatatá! sangue jorra como água. Do ouvido, da boca e nariz. O Senhor é meu pastor...perdoe o que seu filho fez. Morreu de bruços no salmo 23, sem padre, sem repórter .sem arma, sem socorro. Vai pegar HIV na boca do cachorro. Cadáveres no poço, no pátio interno.(...), Fleury e sua gangue vão nadar numa piscina de sangue. Mas quem vai acreditar no meu depoimento? Dia 3 de outubro, diário de um detento ${ }^{27}$." (sublinhados meus)

Encerro a sessão desse cinematógrafo das letras ${ }^{28}$, uma fronteira entre o falar e o ver que combinou a complexidade visual aos sintagmas nominais. Procurei metamorfosear a imagem/tempo em um texto que colocasse em cena, não corpos de prisioneiros/as, mas a trama complexa da carceralização em diferentes cenas discursivas. Neste sentido, a subjetividade como construto reafirma não o sujeito no documentário porém, com uma intensidade surpreendente, o sujeito do documentário no dizer Nichols (1991, p.156). Enfim, ativei a palavra/ imagem como uma forma especial de escritura/manifesto, uma tentativa de fazer emergir uma história subjetivada, ou seja, afetada com a banalização da violência, o descaso com a vida que se expressa na fala de Mano Brown: " O ser humano é descartável no Brasil como modess usado ou bombril."

\section{Fontes:}

Levantamento Nacional de Informações Penitenciárias - INFOPEN- junho de 2014; DEPEN Departamento Penitenciário Nacional- Ministério da Justiça.

\footnotetext{
${ }^{27}$ Ver Diário de um Detento no CD Sobrevivendo no Inferno, letra de Jocenir música de Mano Brown,gravado pelos Racionais Mc's

${ }^{28}$ Inspirado no dizer de Flora Sussekind "Cenas de cinema percorrem este texto e, a seu modo, the servem de epígrafe", no caso os momentos finais deste ensaio.(1987,p.11)

Dossiê Transversos: O Corpo na História e a História do Corpo, Rio de Janeiro, v. 05; n. 05; Ano 02. dez. 2015.
} 
Disponível em: http://www.justica.gov.br/noticias/mj-divulgara-novo-relatorio-do-infopen-nestaterca-feira/ relatorio-depen-versao-web.pdf. Acesso em 20 de fevereiro de 2015.

Justiça, 2003, Maria Augusta Ramos.

Disponível em: http://www.youtube.com/watch?v=r8vaMUOHQNY

Prisioneiro da Grade de Ferro - Auto Retratos - Paulo Sacramento, 2003. Casa de Detenção de São Paulo - Carandiru.

Disponível em: http://www.youtube.com/watch?v=dlIv7Pg5Ud0

\section{Referências Bibliográficas}

AUMONT, Jacques Marie Michel L’Analyse des Films, Nathan, 2aEd, 1988.

A estética do Filme. São Paulo: Papirus Editora, 1995.

BAUMAN, Zygmunt. Os estranhos da era do consumo do Estado do bem estar à prisão. In: O mal estar da pós modernidade. Rio de Janeiro: Jorge Zahar Ed.,1998.

BAZIN, André. O que é o cinema. São Paulo: Cosac Naify, 1991.

CARRIĖRE, Jean. A Linguagem Secreta do Cinema (1931). Rio de Janeiro: Nova Fronteira, 2006.

CERTEAU, Michel. A invenção do cotidiano. Petrópolis, Rio de Janeiro: Vozes, 1994.

DELEUZE, Gilles. Cinema: a imagem movimento. Brasiliense, Rio de Janeiro, 1983.

; GUATTARI, Felix. Preface In: Anti-Oedipus: Capitalism and

Schizophrenia, Deleuze NewYork, Viking Press, 1977.

LUCENA JR, Albert. Arte da animação: técnica e estética através da História. São Paulo: Senac, 2002.

FOUCAULT, Michel "Est-il donc important de penser?" Entrevista com Didier Eribon. Libération, n 15, 30-31 maio de 1981, p. 21. Traduzido a partir de FOUCAULT, Michel. Dits et Écrits. Paris: Gallimard, 1994, vol. IV, pp. 178-182

Vigiar e Punir: História da Violência nas prisões. Petrópolis: Vozes, 1987.

In: Barros, Manoel (org.) Ditos e Escritos. vol. IV. Estratégias de Poder -Saber. Rio de Janeiro: Forense Universitária, 2006.

LUZ, Rogério. Sujeito e narração no cinema. In: Cadernos de Subjetividades- Núcleo de Estudos Dossiê Transversos: O Corpo na História e a História do Corpo, Rio de Janeiro, v. 05; n. 05; 
e Pesquisas da subjetividade do Programa de Pós Graduados em Psicologia. PUC-SP., v.3 nํ1, 1995, p. 42

MOURÃO, Maria Dora; LABAKI, Ami (Org.). O Cinema do real. São Paulo: Cosac Naif, 2005.

NICHOLS, Bill. Blurred Boundaries. Blooming. Indiana University Press,1944

RAGO, Margareth. Foucault, História e Anarquismo. Rio de Janeiro: Achiamé, 2004.

SCUDDER, Priscila Xavier. A arte de morar em cubículos: um diagrama auto/otobiográfico com Nietzsche e prisioneiros sobre a prisão. Tese de doutorado defendida no Programa de Pós Graduação em Educação da Universidade Federal de Mato Grosso, 2012.

SILVA, Marilene Rosa Nogueira da Silva. A Carceralização da escravidão: a emergência de um problema. In: Revista Maracanan, Dossiê Diferenças e Desigualdades Sociais, Revista do Programa de Pós Graduação em História -PPGH/UERJ,DEZ2008.

Madame Satã: uma estética marginal. In: NOVOA, Jorge; ASSUNÇÃO, José. Cinema e História: teorias e representações sociais do cinema. 3 edição Rio de Janeiro: Apicuri, 2012.

Condenados pelo ventre In: Revista História da Biblioteca Nacional. Rio de Janeiro, vol. 2014.

SPIVAK, Gayatri Chakravorty. Pode o subalterno falar? Belo Horizonte, Editora da UFMG,2010. SUSSEKIND, Flora. O Cinematógrafo de Letras: Literatura, técnica e modernização no Brasil. São Paulo: Cia das Letras, 1987.

TOSCANO, Alberto. O Intolerável- Investigação, os Documentos do Grupo de Informação sobre as prisões In: https://viewpointmag.com/2013/09/25/the-intolerable-inquiry-thedocuments-of-the-groupe-dinformation-sur-les-prisons

VERTOV, Dziga.Kino Eye. The writting of Dziga Vertov. Trad.de Kevin O'Brien, Berkeley: University of Californian Press,1984.

WACQUANT, Loic. Punir os pobres: a nova gestão da miséria nos Estados Unidos. Rio de Janeiro: Renavan, 2003

Dossiê Transversos: O Corpo na História e a História do Corpo, Rio de Janeiro, v. 05; n. 05; Ano 02. dez. 2015. 


\section{Como citar:}

SILVA, Marilene Rosa Nogueira da. Corpos encarcerados em cena. Revista Transversos. “Dossiê: O Corpo na História e a História do Corpo”. Rio de Janeiro, Vol. 05, nº . 05, pp. 23. 42, Ano 02. dez. 2015. Disponível em: <http://www.e-publicacoes.uerj.br/index.php /transversos >. ISSN 2179-7528. DOI: 10.12957/transversos.2015.19794.

Dossiê Transversos: O Corpo na História e a História do Corpo, Rio de Janeiro, v. 05; n. 05; Ano 02. dez. 2015. 